\title{
RECENT AND FUTURE TRENDS OF BEACH ZONE EVOLUTION IN RELATION TO ITS PHYSICAL CHARACTERISTICS: THE CASE OF THE ALMIROS BAY (ISLAND OF CRETE, SOUTH AEGEAN SEA)
}

\author{
PETRAKIS S. ${ }^{1, *}$ \\ ALEXANDRAKIS G. ${ }^{1,2}$ \\ POULOS $\mathrm{S}^{1}$
}

\author{
${ }^{1}$ Department of Geography \& Climatology \\ Faculty of Geology \& Geoenvironment \\ National \& Kapodistrian University of Athens \\ Panepistimioupolis - Zografou, 15784, Greece \\ ${ }^{2}$ Institute of Applied \& Computational Mathematics \\ Foundation for Research and Technology, Hellas, N. Plastira \\ 100, Vassilika Vouton, 70013 Heraklion, Crete, Greece
}

Received: 08/02/12

Accepted: $14 / 03 / 13$ *to whom all correspondence should be addressed: e-mail: spetrakis@geol.uoa.gr

\begin{abstract}
The present study investigates recent and future evolution of the beach zone of Almiros Bay, one of the most touristic developed beaches of north Crete, in relation to its morphodynamic setting and the anticipated sea level rise. The beach zone is exposed to northerly winds, with maximum wave heights and periods of $4.3 \mathrm{~m}$ and $9 \mathrm{~s}$, respectively.

The comparison of the aerial photographs (1982-1996) and a satellite image of 2007 have revealed an extended retreat of the beach zone, with its highest retreating rates (i.e. 0.6-0.8 $\mathrm{m} \mathrm{y}^{-1}$ for the last 25 years) found at its central part. Moreover, an estimation of the future shoreline retreat, due to the anticipated sea level rise (i.e. 0.38 or $1 \mathrm{~m}$ for the year 2100), has shown that there is a potential coastal zone loss from $48 \%$ up to $100 \%$, respectively. A gross evaluation of the economical impact due to the aforementioned beach loss accounts to approximately from $\$ 270,000$ up to $\$ 720.000$, annually.
\end{abstract}

KEYWORDS: shoreline retreat, N. Crete, erosion, land loss, touristic beaches.

\section{INTRODUCTION}

Tourism plays a very important role in the social and economical development of Greece, as it has been ranked as one of the top 20 touristic destinations, globally. This highlights the significance of the preservation of the Greek beach zones, where the international visitors seek the traditional "sun, sea and sand" package vacations (Anastassopoulos et al., 2009). Crete, in particular, has a large economical profit from tourism and is interested in maintaining this wealth-source for the prosperity of the local and national population. Coastal erosion and especially beach erosion, is obviously a threat for the local and national economy; usually, it can be caused by a combination of factors, natural and anthropogenic, resulting in two types of hazards: (a) loss of land and/or distraction/degradation of the coastal environment, with economic consequences; and (b) the undermining of coastal infrastructure.

Coastal erosion is defined as the long term loss of the shore material relatively to a fixed reference line (baseline). It is a very complex natural phenomenon, caused by a variety of natural processes that change in space and time. The main characteristics of the beach zone that control coastal erosion are: (i) the beach and coastal zone slope, (ii) the lithology, (iii) the nearshore wave regime, (iv) the frequency of storm events, and (v) the anthropogenic interventions (Pranzini and Rossi, 1995; Khalil, 1997; Berriolo et al., 2001; Medina and Lopez, 1997). Moreover, according to the moderate scenario A1B of IPCC (2007), a mean sea-level rise of $0.38 \mathrm{~m}$ for the year 2100 has been predicted, while other scientists (e.g. Rahmstorf, 2007; Pfeffer et al., 2008), have predicted a SLR of 
more than $1 \mathrm{~m}$. Such rates will cause a significant retreat in the majority of the coastlines and particularly in beach zones that are exposed to high wave energy.

Costanza et al. (1997) have tried to convert "land-loss" to "money-loss", by estimating the financial value of ecosystem services worldwide. They have concluded that considering only the coastal environments, the annual Total Global Flow Value is about $\$ 12.6 \times 10^{13}$, with an average estimation of $\$ 4 \times 10^{3}$ for every coastal hectare $\left(10^{4} \mathrm{~m}^{2}\right)$, being also the most significant coastal ecosystems. According to these estimates, each Greek coastal hectare accounts on an annual basis of about $\$ 9$ 10,000 (in prices of 1997).

Cretan coast is under extended erosion, as its $65.8 \%$ of coastline is retreating, when the average percent of the total coastline length of Greece is about 30\% (EUROSION, 2001); this large percentage of eroding coastline of Crete is related to its extended presence of beach zones. Alexandrakis et al. (2006) have shown that the northern coast of Crete, in all of its length, presents the highest vulnerability to erosion, in comparison to other coastal areas of Greece. Thus, for the Cretan and national welfare, very important measures have to be taken in order to mitigate the impact of beach erosion, due to the anticipated SLR caused by climate change.

The present research concerns recent and future trends of shoreline evolution, based on anticipated SLR, in the case of the Almiros Bay tourist beach (see Figure 1), which is exposed to medium to high wave energy, is characterized by the mouths of four small rivers (or ephemeral streams) and is under intensive touristic development.

\section{STUDY AREA}

Almiros Bay is located at the western part of the northern coast of Crete, with a coastline length of approximately $9.5 \mathrm{~km}$. It includes a sandy beach zone associated with a low relief dune field, in front of an alluvial (Holocene in age) plain, consisted by alluvial, marl and riverine deposits; the latter is an agricultural field with vineyards, olive trees and graze land. In the Almiros bay four rivers debouch, Almiros $\left(160 \mathrm{~km}^{2}\right)$, Delfinas $\left(39 \mathrm{~km}^{2}\right)$, Mouselas $\left(51 \mathrm{~km}^{2}\right)$ and Petres $\left(140 \mathrm{~km}^{2}\right)$, together with four smaller torrents (Fig. 1). Furthermore, the hinterland area to the west of river Mouselas is included in the Natura_2000 network (site-code: GR4340010), which is categorized in "Special Protection Areas (SPA), for Sites Eligible for identification as sites of community importance (SCI) and for Special Areas of Conservation (SAC)". Within this framework and according to results of the Life project, (LIFE04NAT/GR/000105) this area has been recognized to be most vulnerable to: (i) construction of seasonal residencies, (ii) construction of new touristic facilities, (iii) extension of arable ground, (iv) extensive irrigation, (v) hunting, (vi) grazing and (vii) waste from oil-industry.

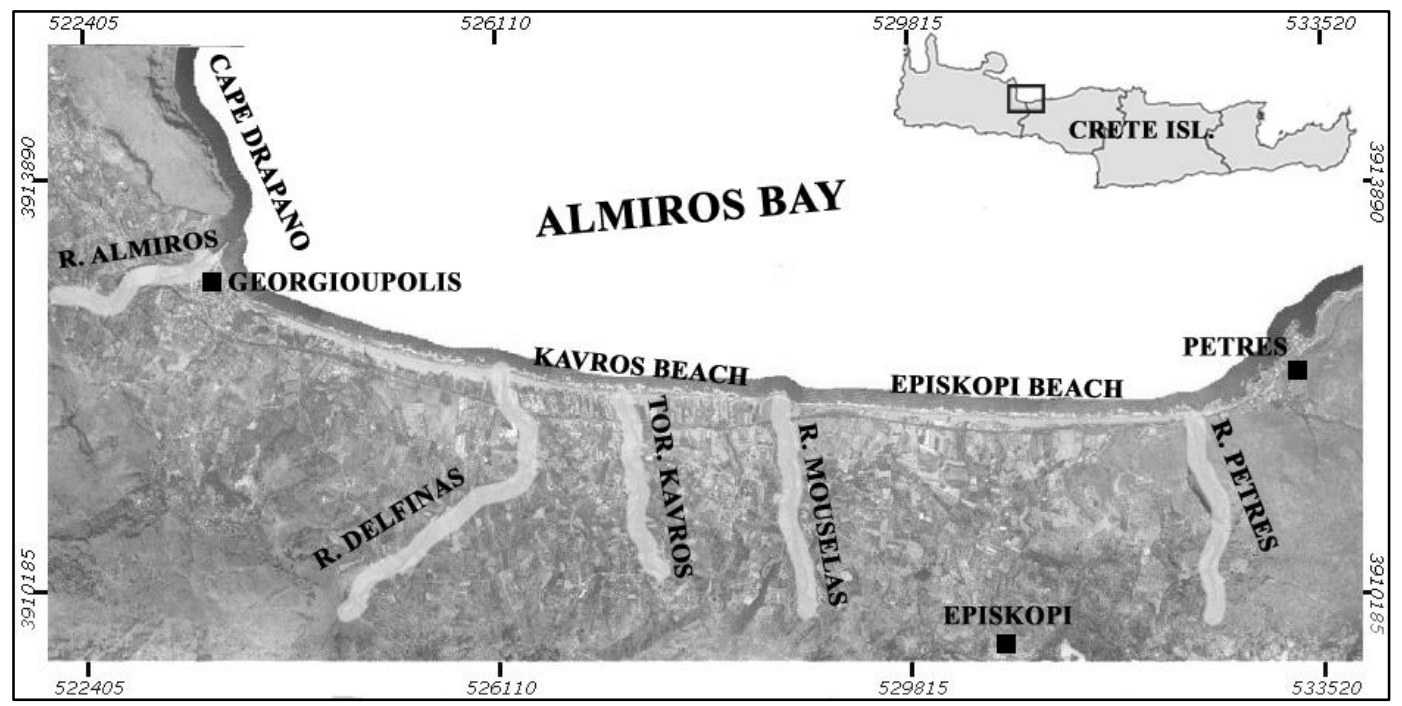

Figure 1. Map of the Almiros beach zone

(background picture obtained from Ktimatologio S.A, 2007)

The Almiros Bay includes the beach zones of Georgioupolis (western sector), Kavros (central sector) and Episkopi (eastern sector) (Figure 1), with Georgioupolis and Kavros beach zones to be more 
tourist developed with large hotels, beach facilities, parking lots etc, compared to the Episkopi beach zone.

The Almiros Bay is exposed to northerly winds (NW, N and NE), with NW winds being the most frequent, with an annual frequency of occurrence of $25.5 \%$. However, the small fetch distances of the NW wind-induced waves $(7.7 \mathrm{~km})$, due to the presence of cape Drapano, are related to offshore waves with significant heights of $<1 \mathrm{~m}$ and periods of $<3.5 \mathrm{~s}$. On the contrary, $\mathrm{N}$ winds, with an annual frequency of occurrence of $14.4 \%$, and a fetch of $176.5 \mathrm{~km}$, generate waves with significant heights and periods that can reach the $4.3 \mathrm{~m}$ and $9 \mathrm{~s}$, respectively. NE waves, even though they are generated over the biggest fetch distance $(208 \mathrm{~km})$, due to their small frequency of occurrence (only $3.0 \%$ ), have significant wave heights and periods of up to $2 \mathrm{~m}$ and $7.2 \mathrm{~s}$ (Soukissian et al., 2007).

In Table 1, the main characteristics of the incoming offshore waves are presented, together with their characteristics in the nearshore zone (after Alexandrakis et al., 2011). According to wave run-up ability and the closure depth values, the beach zone of the Almiros Bay seems to be extending landwards, to elevations of $\sim 2.5 \mathrm{~m}$ and seawards to water depths of about $10 \mathrm{~m}$. The beach zone undergoes small astronomical tidal ranges $(<20 \mathrm{~cm})$ (Tsimplis, 1994), although sea surface can rise sporadically, mostly due to storm surge, that can exceed $0.5 \mathrm{~m}$; as deduced by sea level measurements in the ports of Souda (western Crete) and Heraklion (central Crete) (HHS, 2004).

Table 1. Wave regime of the beach zone $\left(F^{2}\right.$ tch $\left._{\max }=176.5 \mathrm{~km}\right)$; most frequent (MF) and maximum (MAX) are presented for: wind speed $(\mathrm{Ua})$; wave period $\left(T_{p}\right)$; significant height $\left(H_{s}\right)$; closure depth $\left(\mathrm{h}_{\mathrm{c}}\right)$; breaking height $\left(\mathrm{H}_{\mathrm{b}}\right)$; breaking depth $\left(\mathrm{h}_{\mathrm{b}}\right)$ and run-up $(\mathrm{R})$

\begin{tabular}{|c|c|c|c|c|c|c|c|c|c|}
\hline & Wind & $\underset{\left(\mathrm{m} \mathrm{s}^{-1}\right)}{\mathrm{Ua}}$ & $\begin{array}{l}\text { freq } \\
(\%)\end{array}$ & $\begin{array}{c}T_{p} \\
(\mathbf{m})\end{array}$ & $\begin{array}{c}\mathbf{H}_{\mathbf{s}} \\
(\mathbf{m})\end{array}$ & $\begin{array}{c}h_{c} \\
(m)\end{array}$ & $\begin{array}{c}H_{b} \\
(\mathbf{m})\end{array}$ & $\begin{array}{c}d_{b} \\
(m)\end{array}$ & $\begin{array}{c}R \\
(\mathbf{m})\end{array}$ \\
\hline \multirow{3}{*}{ MF } & $\mathrm{N}$ & 8.32 & & 6.76 & 1.79 & 4.07 & 2.11 & 2.29 & 2.47 \\
\hline & NE & 3.32 & & 5.27 & 0.77 & 1.76 & 0.98 & 0.99 & 0.57 \\
\hline & NW & 6.64 & & 2.23 & 0.30 & 0.68 & 0.32 & 0.38 & 0.38 \\
\hline \multirow{3}{*}{ MAX } & $\mathrm{N}$ & 19.85 & 0.20 & 9.01 & 4.26 & 9.70 & 4.75 & 5.47 & 3.8 \\
\hline & NE & 8.46 & 0.10 & 7.18 & 1.97 & 4.49 & 2.34 & 2.53 & 0.94 \\
\hline & NW & 19.85 & 0.10 & 3.21 & 0.89 & 2.03 & 0.90 & 1.14 & 0.59 \\
\hline
\end{tabular}

\section{DATA COLLECTION AND METHODOLOGY}

For the morphological mapping of the study areas, topographic maps (1:5000, published by the Hellenic Army Geographical Service (H.A.G.S.)), geological maps of the study areas (scale 1:50.000, published in 1989, by the Institute of Geological and Mineral Exploration (IGME)) and an aerial photograph of 2007 (source: KTIMATOLGIO S.A.) were used. The morphological measurements included 8 descriptive shore-normal profiles along the beach zone, which extended from the sand dunes to the depth of $\sim 5 \mathrm{~m}$. Beach elevations and slopes were measured with the use of a laser distance meter and a GPS device, whilst depth soundings (at distances of every $5 \mathrm{~m}$ ) were taken with the use of a portable echo-sounder (accuracy $\pm 3 \mathrm{~cm}$ ), up to a water depth of about $5 \mathrm{~m}$.

In order to investigate recent coastline evolution, the latter was divided into 6 sections according to its orientation and geomorphological characteristics (Figure 4). Subsequently, coastline spatial changes were identified with the comparison of air-photographs of the years 1982 and 1996 and a Satellite Image from 2007. The air-photographs and satellite image were corrected geometrically, and the maximum total error (from coastline definition and digitizing) was estimated to be $\pm 2 \mathrm{~m}$.

The future coastline retreat $\left(R_{\infty}\right)$, due to the anticipated SLR and incorporating the effect of storm surge, has been estimated utilizing the Dean's (1991) (1) and Kriebel \& Dean's (1993) (2) semiempirical equations:

$$
R_{\infty}=\left(S+0.068 H_{b}\right) \cdot\left(\frac{W_{b}}{B+h_{b}}\right)
$$




$$
R_{\infty}=S \frac{W_{b}-\frac{H_{b}}{m_{o}}}{h_{b}+B-\frac{S}{2}}
$$

where: $S$ is the relative mean SLR (in $\mathrm{m}$ ); $\mathrm{W}_{\mathrm{b}}$ is surf zone length, i.e the horizontal distance from wave breaking zone to shoreline; $m_{0}$ is the slope of beach profile at the coastline; $H_{b}$ is wave breaking height; $h_{b}$ is wave breaking depth; and $B$ is the subaerial berm height.

\section{RESULTS-DISCUSSION}

The subaerial part of the Almiros beach zone can be generally divided into three sectors, with respect to the presence of the torrents' mouths. The western part (sector 1) includes the area between Almiros and Delfinas torrents. In this sector, the beach zone presents its largest width ( 80 $\mathrm{m})$. The central part (sector 2) includes the area between Delfinas and Mousselas torrents; with a beach zone width less than $50 \mathrm{~m}$. The eastern part (sector 3 ) includes the area between Mousselas and Petres torrents, having a beach width of approximately $60 \mathrm{~m}$. As shown in figure 2, the majority of the beach zone granulometry, according to Folk (1980), is characterized as sand and gravelly sand, except for the central part of the study area (profiles III-VI), where the beach sediment is coarser and is characterized as gravel and sandy gravel.

The inshore zone is characterized by the presence of underwater welded (crescentic) sandy bars (Figure 3), which are extending to water depths of 2-2.5 m, in a horizontal distance of $\sim 100 \mathrm{~m}$ from the coastline. This shape of underwater bars usually occurs at unprotected coasts to incoming waves, with an inshore zone of very small slopes (Carter, 1988), such as that of the Almiros bay, while absolute crescentic in-shape bars are formed under high wave energy. Furthermore, this type of sandy inshore formations relates to sediment recycling between the breaking zone and the crest of the lowest subaerial berm.

The surficial sediment of Sector 1 (profiles I \& II) is mainly sandy (S), except on the crest of the berm, where it becomes coarser, being gravelly sand (gS). The surficial sediments of the subaqueous beach zone are characterized as slightly gravelly Sand $((\mathrm{g}) \mathrm{S})$, up to the depth of $\sim 4 \mathrm{~m}$. The slope of the beach zone is generally smooth $(\sim 2 \%)$, while at the beach face the slope is approximately $5 \%$. At water depths of $\sim 1.5 \mathrm{~m}$ and $\sim 2.5 \mathrm{~m}$ (corresponding distances from the coastline $60-80 \mathrm{~m}$ and $\sim 200 \mathrm{~m}$ ), troughs followed by a bar of $\sim 0.5 \mathrm{~m}$ high are observed. Due to the fact that these bars are present in all 8 profiles, it is considered that their formation is related to the presence of the above described alongshore welded bars. Furthermore, the trough-bar system, which is closer to the coastline, is formed by the most frequent incoming waves, while the trough-bar system at the water depth of $2.5 \mathrm{~m}$, is formed by the highest (and less frequent) waves (for details see Table 1).

In sector 2 (profiles III \& IV), the subaerial part of the beach zone has a width of $\sim 40 \mathrm{~m}$, with a smooth slope of about $\sim 2 \%$ towards the sea. Sediments are generally coarser grained, i.e. sandy gravel (sG) in relation to the other two sectors. The beach face has an increased slope of $6-7 \%$ consisted by gravelly sand and sandy gravel. The subaqueous surficial sediments are characterized as sand (S) and slightly gravelly sand $((\mathrm{g}) \mathrm{S})$. The subaqueous beach zone slope at the first $80 \mathrm{~m}$ varies from $\sim 1 \%$ (profile III) to $\sim 3 \%$ (profile IV). Deeper within and for the next $20 \mathrm{~m}$, the slope increases to $3.5 \%$ (corresponding distances from the coastline $\sim 100 \mathrm{~m}$ ) and then flattens until the depth of $\sim 3 \mathrm{~m}$, where the permanent bar exists. At the end of sector 2 , the width of the subaerial beach zone reaches its smallest width $(<20 \mathrm{~m})$.

Sector 3 (profiles V-VIII) has a subaerial width of about $40 \mathrm{~m}$, consisted by sand (S) and slightly gravelly sand $((\mathrm{g}) \mathrm{S})$. The subaerial slope of the beach is $\sim 3 \%$, while the slope of the beach face is $\sim 7 \%$; the latter consists of relatively coarser material, i.e. sandy gravel (sG) - gravel (G). Subaqueous slopes are in the order of $1-3 \%$ and the surficial sediments are characterized as slightly gravelly sandy $((\mathrm{g}) \mathrm{S})$ to sandy $(\mathrm{S})$. There is a trough-bar formation in a 10-15 m distance from the shoreline, with an elevation of $0.5 \mathrm{~m}$, while a second trough-bar appears in various distances from the coastline, being slightly smaller than the first one. 

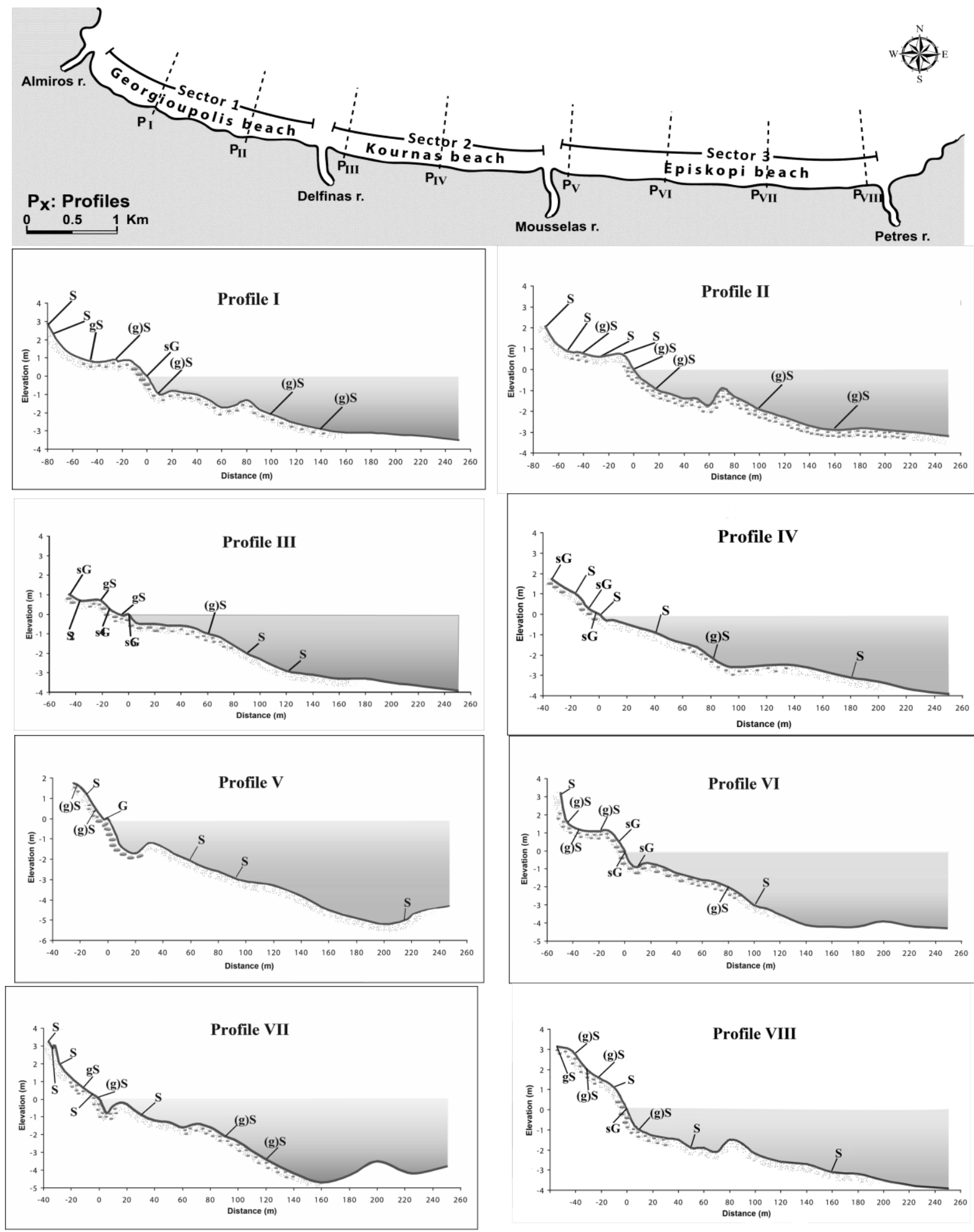

Figure 2: Current morphology and granulometry along the eight normal profiles of Almiros shoreline face 


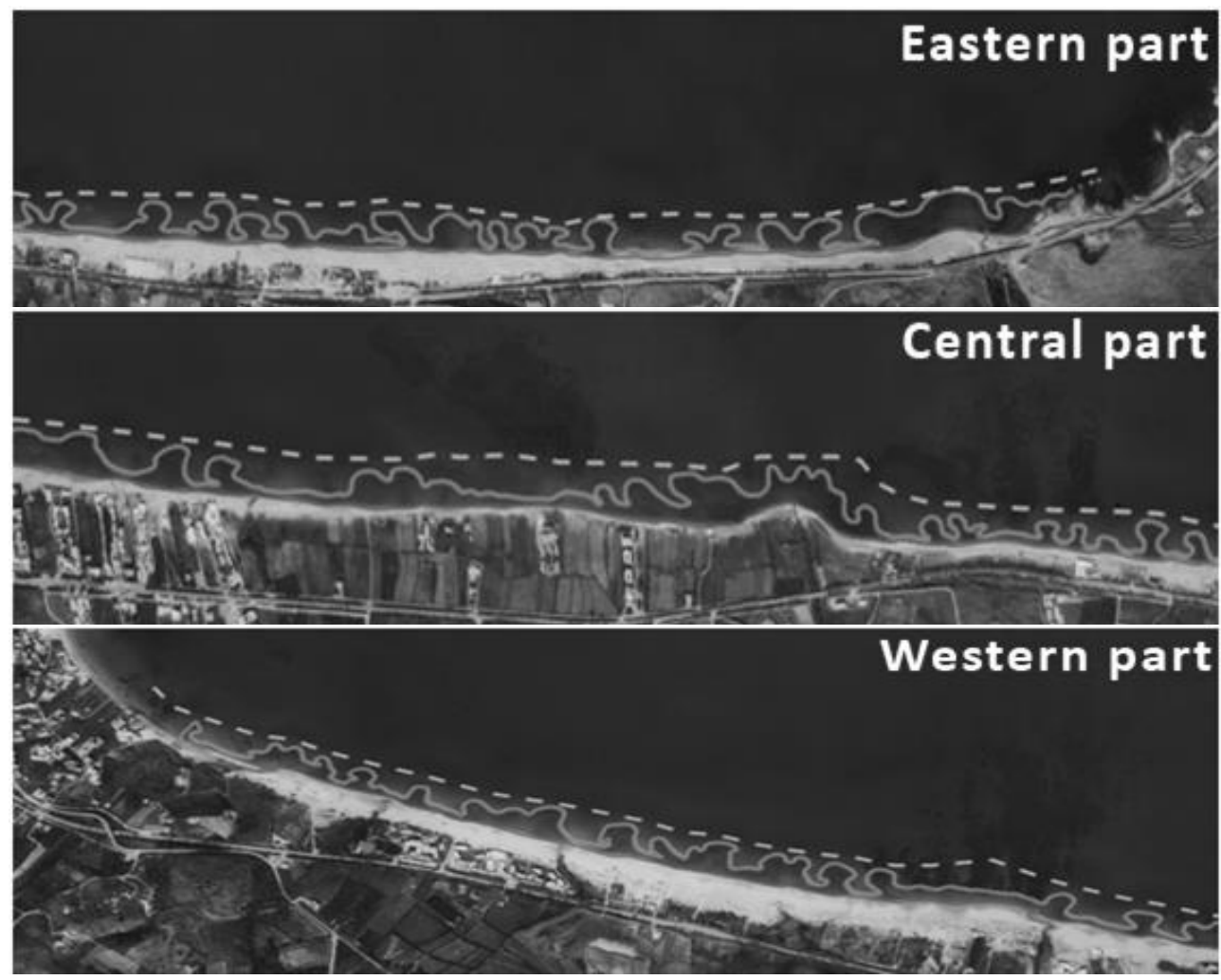

Figure 3. Inshore zone and underwater bars morphology along the three sectors of the Almiros Beach zone

\section{Recent shoreline evolution}

The comparison of shoreline position in 1982, 1996 \& 2007 shows that the Almiros beach zone is characterized by a mixed picture, considering the achieved accuracy of $\pm 2 \mathrm{~m}$, with areas rather stable and areas with variable rates of shoreline retreat (Figure 4 - Table 2). More specifically, in section (a) the measured retreat is about $15 \pm 2 \mathrm{~m}$ that corresponds to an annual rate of retreat, equal to $0.6 \mathrm{~m} \mathrm{yr}^{-1}$. The shoreline displacement in sections (b) and (c) are within the limit of accuracy ( \pm 2 $\mathrm{m}$ ) and, therefore, they may be considered as rather stable. This can be explained from the fact that the western part of the Almiros Bay is semi-protected by the prevailing NW winds and the induced by them waves and nearshore currents. Section (d) presents the highest shoreline retreat, in the order of 15-20 m that corresponds to an annual rate of 0.6-0.8 $\mathrm{m} \mathrm{y}^{-1}$. In section (e), as in sections (d) and (c), there is no significant shoreline change. In the eastern section (f), shoreline retreat accounts for 7-8 $\mathrm{m}$, with annual rate of $0.3 \mathrm{~m} \mathrm{yr}^{-1}$.

Table 2. Decadal \& annual rates of coastline retreat for each section of the Almiros Bay

\begin{tabular}{cccc}
\hline Section & $\begin{array}{c}\text { Total Retreat } \\
(\mathbf{m})\end{array}$ & $\begin{array}{c}\text { Area of beach } \\
\text { loss }^{2}\left(\mathbf{k m}^{2}\right)\end{array}$ & $\begin{array}{c}\text { Annual rate of retreat for the period } \\
\mathbf{1 9 8 2 - 2 0 0 7}\left(\mathbf{m ~} \mathbf{~} \mathbf{r}^{-1}\right)\end{array}$ \\
\hline $\mathrm{a}$ & 15 & 0.045 & 0.6 \\
\hline $\mathrm{b}$ & - & - & - \\
\hline $\mathrm{c}$ & - & - & - \\
\hline $\mathrm{d}$ & $15-20$ & $0.05-0.06$ & $0.6-0.8$ \\
\hline $\mathrm{e}$ & - & - & - \\
\hline $\mathrm{f}$ & $7-8$ & 0.08 & $0.28-0.32$ \\
\hline
\end{tabular}

$\left({ }^{1}\right)$ : accuracy of coastline retreat equals to $\pm 2 \mathrm{~m}$

$\left({ }^{2}\right)$ : accuracy of the estimated lost area equals to $\pm 0.05 \mathrm{~km}^{2}$.

\section{Expected shoreline retreat due to future sea level rise}

Estimations of the Almiros bay shoreline retreat due to the anticipated SLR, including the effect of storm waves were computed for two scenarios of SLR, referred to the year 2100: the A1B scenario 
of IPCC (2007) that predicts SLR=0.38 cm; and the scenario of SLR=1 m, according to Pfeffer et al. (2008). On the basis of these estimations, shoreline retreat of the Almiros Bay ranges from $26.5 \mathrm{~m}$ up to $33.3 \mathrm{~m}$. Exception to this is the eastern part of the beach zone (profile VIII), in which the maximum estimated retreat can reach up to $63 \mathrm{~m}$. These values, considering the morphological characteristics of the beach zone, can lead to a mean land loss of $37.5 \%$ in Sec. 1, 66.7\% in Sec. 2 and $50 \%$ in Sec. 3 (Table 3).

Table 3. Estimate of shoreline retreat $\left(\mathrm{R}_{\infty}\right.$, in $\left.\mathrm{m}\right)$ for the 8 profiles and corresponding area loss $\left(A\right.$, in $\left.\mathrm{km}^{2}\right)$ of the Almiros Bay, in response to future sea level rise (SLR) of $0.38 \mathrm{~m}$ and $1 \mathrm{~m}$ (for profile and sector locations, see Figure 2)

\begin{tabular}{|c|c|c|c|c|c|c|c|c|c|}
\hline \multirow[t]{2}{*}{$\begin{array}{c}\text { Sectors } \\
\text { (Area) }\end{array}$} & \multirow[t]{2}{*}{ Profiles } & \multicolumn{4}{|c|}{ SLR $=0.38 \mathrm{~m}$} & \multicolumn{4}{|c|}{ SLR $=1 \mathrm{~m}$} \\
\hline & & $\begin{array}{l}\mathbf{R}_{\infty}(\mathbf{m}) \\
\text { Dean, } \\
\text { 1991) }\end{array}$ & $\begin{array}{c}\mathbf{R}_{\infty}(\mathrm{m}) \\
\text { (Kriebel \& } \\
\text { Dean,1993) }\end{array}$ & $\begin{array}{c}\text { Estimated } \\
\text { area loss } \\
\left(\mathrm{km}^{2}\right)\end{array}$ & $\%$ & $\begin{array}{l}R_{\infty}(m) \\
\text { (Dean, } \\
\text { 1991) }\end{array}$ & $\begin{array}{c}\mathbf{R}_{\infty}(\mathbf{m}) \\
\text { (Kriebel \& } \\
\text { Dean,1993) }\end{array}$ & $\begin{array}{l}\text { Estimated } \\
\text { area loss } \\
\left(\mathrm{km}^{2}\right)\end{array}$ & $\%$ \\
\hline \multirow{2}{*}{$\begin{array}{c}1 \\
\left(0.25 \mathrm{~km}^{2}\right)\end{array}$} & I & 31.7 & 28.3 & \multirow{2}{*}{0.09} & \multirow{2}{*}{37,5} & 87.2 & 77.9 & \multirow{2}{*}{0.245} & \multirow{2}{*}{100} \\
\hline & II & 31.3 & 30.7 & & & 86.1 & 84.5 & & \\
\hline \multirow{2}{*}{$\begin{array}{c}2 \\
\left(0.11 \mathrm{~km}^{2}\right)\end{array}$} & III & 31.1 & 27.6 & \multirow{2}{*}{0.075} & \multirow{2}{*}{66,7} & 85.5 & 75.8 & \multirow{2}{*}{0.2} & \multirow{2}{*}{100} \\
\hline & IV & 33.3 & 31.4 & & & 91.6 & 86.2 & & \\
\hline \multirow{4}{*}{$\begin{array}{c}3 \\
\left(0.21 \mathrm{~km}^{2}\right)\end{array}$} & $\mathbf{V}$ & 30.5 & 28.4 & \multirow{4}{*}{0.11} & \multirow{4}{*}{50} & 83.9 & 78.02 & \multirow{4}{*}{0.28} & \multirow{4}{*}{100} \\
\hline & VI & 28.3 & 30.1 & & & 77.8 & 82.7 & & \\
\hline & VII & 30.8 & 26.5 & & & 84.7 & 72.9 & & \\
\hline & VIII & 28.6 & 63.0 & & & 78.7 & 173.2 & & \\
\hline Total & & & & 0.27 & 48 & & & 0.72 & 100 \\
\hline
\end{tabular}

According to Table 3, the anticipated retreat due to a SLR of $0.38 \mathrm{~m}$ will cause the loss of $0.27 \mathrm{~km}^{2}$, which corresponds to $48 \%$ of the present subaerial beach zone area, while the $1 \mathrm{~m} \mathrm{SLR}$ will result to losing a great percentage of the Almiros beach zone. Those estimations are extremely important for the local community, since its economy depends on the exploitation of the coastal zone, including its beach zone; thus, socio-economic activity is primarily based on touristic facilities (e.g. hotels, bungalows, taverns, bars etc.) and, secondarily, on agriculture. Moreover, according to Costanza et al.'s (1997) study, a $0.27 \mathrm{~km}^{2}$ land loss of coastal area corresponds to a potential economical loss of income of $\$ 270,000$ annually, whereas the loss of the total coastal area will raise the cost to $\$$ 720,000 annually; these estimates do not take into consideration the environmental degradation of the area due to beach loss.

\section{CONCLUSIONS}

The beach zone of the Almiros bay has a shoreline length of about $9 \mathrm{~km}$ and a width that ranges from a few meters up to $80 \mathrm{~m}$. Its subaerial part consists, generally, of sand (S) and locally of gravelly sand (gS) and sandy gravel (sG). Its morphology is characterized by subaerial slopes of $\sim 2 \%$, with its beach face being steeper (up to 7\%). The subaqueous part is smoother with slopes of $\sim 2 \%$. Two major trough-bar formations are observed, at water depths of $60-80 \mathrm{~m}$ and $200 \mathrm{~m}$, which are related to the most frequent $\left(H_{s}=1.79 \mathrm{~m} \mathrm{~T}_{p}=6.76 \mathrm{~s}\right)$ and maximum $\left(H_{s}=4.26 \mathrm{~m} \mathrm{~T}_{p}=9.01 \mathrm{~s}\right)$ wave conditions, respectively. These formations of the inshore zone are associated with the presence of the almost crescentic welded bars, whose formation is related to nearshore hydrodynamics induced by the wave activity.

During the past 25 years, the eastern and central part of the Almiros bay has presented a retreat of up to $15 \mathrm{~m}$, while its western part seems to be rather stable, as it is protected by the prevailing NW winds and associated wind-generated waves and the induced by them nearshore currents.

Estimates for future shoreline retreat, due to anticipated SLR, provide values of $30 \mathrm{~m}$ for $S L R=0.38$ $\mathrm{m}$ and approximately $80 \mathrm{~m}$ for $\mathrm{SLR}=1 \mathrm{~m}$; the former corresponds to a loss of the $48 \%$ of the present beach (subaerial) area, while the latter to a loss of a great percentage of the existing beach. The aforementioned beach zone losses correspond to an annual economic damage of $\$ 270,000$ and \$ 720,000 , respectively. 


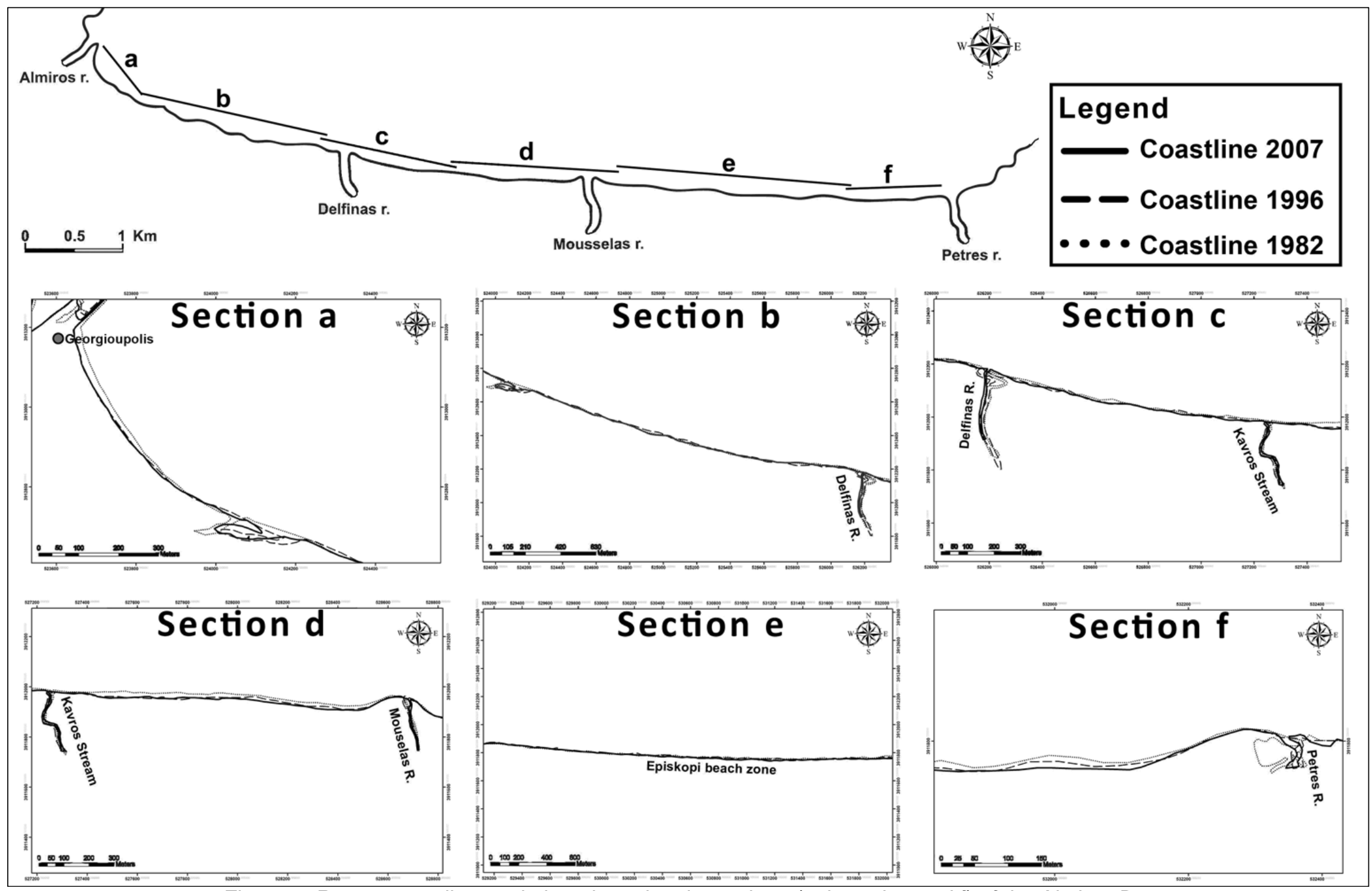

Figure 4. Recent coastline evolution along the six sections ( $a, b, c, d$, e and $f$ ) of the Almiros Bay 


\section{CONCLUSIONS}

The beach zone of the Almiros bay has a shoreline length of about $9 \mathrm{~km}$ and a width that ranges from a few meters up to $80 \mathrm{~m}$. Its subaerial part consists, generally, of sand (S) and locally of gravelly sand (gS) and sandy gravel (sG). Its morphology is characterized by subaerial slopes of $\sim 2 \%$, with its beach face being steeper (up to $7 \%$ ). The subaqueous part is smoother with slopes of $\sim 2 \%$. Two major trough-bar formations are observed, at water depths of $60-80 \mathrm{~m}$ and $200 \mathrm{~m}$, which are related to the most frequent $\left(H_{s}=1.79 \mathrm{~m} \mathrm{~T}_{p}=6.76 \mathrm{~s}\right)$ and maximum $\left(\mathrm{H}_{\mathrm{s}}=4.26 \mathrm{~m} \mathrm{~T}_{\mathrm{p}}=9.01 \mathrm{~s}\right)$ wave conditions, respectively. These formations of the inshore zone are associated with the presence of the almost crescentic welded bars, whose formation is related to nearshore hydrodynamics induced by the wave activity.

During the past 25 years, the eastern and central part of the Almiros bay has presented a retreat of up to $15 \mathrm{~m}$, while its western part seems to be rather stable, as it is protected by the prevailing NW winds and associated wind-generated waves and the induced by them nearshore currents.

Estimates for future shoreline retreat, due to anticipated SLR, provide values of $30 \mathrm{~m}$ for $S L R=0.38$ $\mathrm{m}$ and approximately $80 \mathrm{~m}$ for $\mathrm{SLR}=1 \mathrm{~m}$; the former corresponds to a loss of the $48 \%$ of the present beach (subaerial) area, while the latter to a loss of a great percentage of the existing beach. The aforementioned beach zone losses correspond to an annual economic damage of $\$ 270,000$ and $\$$ 720,000 , respectively.

\section{ACKNOWLEDGEMENTS}

$\mathrm{Dr}$ G. Alexandrakis is grateful to the State Scholarships Foundation for the scholarship that supports his $\mathrm{PhD}$ thesis to which the present contribution is strongly associated.

\section{REFERENCES}

Alexandrakis G., Karditsa A., Poulos S., Ghionis G. and Kampanis N.A.. (2010), An assessment of the vulnerability to erosion of the coastal zone due to a potential rise of sea level: The case of the Hellenic Aegean coast. In Environmental Systems, [Ed. Achim Sydow], in Encyclopedia of Life Support Systems (EOLSS), Developed under the Auspices of the UNESCO, Eolss Publishers, Oxford, UK.

Alexandrakis G., Poulos S., Ghionis G., and Leivaditis G. (2006), A morphological study of a reef with beachrock characteristics, in association with the recent evolution of the Ammoudara beach zone (Heraklion, Crete), Bull. Geological Soc. of Greece, XXXIX/III, 146-155.

Alexandrakis G., Poulos S., Petrakis S. and Collins M. (2011), The development of a Beach Vulnerability Index (BVI) for the assessment of erosion in the case of the North Cretan Coast (Aegean Sea), Hellenic Journal of Geosciences, 45, 11-22.

Anastassopoulos G., Filippaios F. and Phillips P. (2009), An eclectic investigation of tourism multinationals: Evidence from Greece, Intern. J. of Hospitality Management, 28(2), 185-194.

Berriolo G., Fierro G. and Gamboni S. (2001), The evolution of the coast between Cape Farina and Cape Gamarth (Northern Tunisia), (Ozhan E., Ed.), Proc. of the Fifth International Conference on the Mediterranean Coastal Environment, MEDCOAST 01, MEDCOAST Secretariat, Middle East Technical University, Ankara, Turkey, v: 3, pp: 1497-1502.

Bouziotopoulou N., Ghionis G. and Poulos S. (2006), Morphological changes in the shore zone of Gouves-Gournes (N.Crete) due to alterations of its sediment budget caused by human activities, Bulletin of the Geological Society of Greece, XXXIX/III, 135-145.

Bruun P. (1962), Sea-level rise as a cause of shore erosion: Proceedings. American Society of Civil Engineers, Journal of Waterways Harbours Division, 88, 117-130.

Carter R. W. G. (1988), Coastal Environments: An Introduction to the Physical, Ecological, and Cultural Systems of Coastlines, London; San Diego: Academic Press.

CERC (1984), Shore protection Manual. U.S. Army Corps of Engineers Coastal Engineering Research Center, Washington D.C.

Costanza R., d'Arge R, de Groot R, Farber S., Grasso M., Hannon B., Limburg K., Naeem S., O'Neill R., Paruelo J., Raskin R., Sutton P. and van den Belt M. (1997), The value of the world's ecosystem services and natural capital, Nature, 387, 253-260 
Dean R.G. (1991), Equilibrium Beach Profiles: Characteristics and Applications, Journal of Coastal Research, 7(1), 53-84.

EUROSION, (2001). Coastal erosion - Evaluation of the need for action, Directorate General Environment, European Commission

Folk R.L. (1980), Petrology of Sedimentary Rocks, Hemphill Publishing Co, Austin, Texas, 183 pp.

Hellenic Hydrographic Service, 2004.

IPCC (Fourth Assessment Report: Climate Change) (2007), The Regional Impacts of Climate Change: An Assessment of Vulnerability.

Khalil S.(1997), Critical problems of the Egyptian Mediterranean coastal zones, Ozhan E., (Ed.), Proc. of the Third International Conference on the Mediterranean Coastal Environment, MEDCOAST 97, MEDCOAST Secretariat, Middle East Technical University, Ankara, Turkey, v: 1, pp: 513-521.

Kriebel D.L. and Dean R.G. (1993), Convolution method for time-dependent beach profile response, J. Waterways Port, Coastal and Ocean Eng., 119(2), 204-226.

Medina J.M. and Lopez J.S. (1997), Strong erosion scenario due to disequilibrium of solid transport rate: the case of Torrox Beach(Malaga), (E. Özhan, Ed.), Proc. of the Third International Conference on the Mediterranean Coastal Environment, MEDCOAST 97, MEDCOAST Secretariat, Middle East Technical Uni, Ankara, Turkey, v:2,pp:1234-1239.

Natura_2000 (http://www.ekby.gr/ekby/en/Natura2000_main_en.html)

Petrakis S., (2010) Coastal morphodynamic study of the Almyros Bay coastal zone, Georgioupolis, Crete. MSc Thesis, Interdepartmental Master in Oceanography, National \& Kapodistrian University of Athens, Greece. Unpublished.

Pfeffer W.Y., Harper J.T. and O'Neel S. (2008), Kinematic constrains on Glacier Contributions to $21^{\text {st }}$ Century Sea-Level Rise, Science, 321(5894), 1340-1343.

Pranzini E. and Rossi L. (1995), Physical model test in the framework of beach nourishment performance evaluation, Özhan E., (Ed.), Proc. of the Second International Conference on the Mediterranean Coastal Environment, MEDCOAST 95, MEDCOAST Secretariat, Middle East Technical University, Ankara, Turkey, v: 2, pp: 1145-1159.

Rahmstorf S. (2007), Sea-Level Rise: A semi-Empirical Approach to Projecting Future, Science, 315, 368-370.

Soukissian T., Hatzinaki M., Korres G., Papadopoulos A., Kallos G., Anadranistakis E. (2007), Wind and Wave Atlas of the Hellenic Seas, Hellenic Centre for Marine Research Publ., 300 pp., ISBN-987 960 86651 9-4.

Tsimplis M.N. (1994), Tidal oscillations in the Aegean and Ionian Seas. Estuarine, Coastal and Shelf Science, 39(2), 201-208. 